\begin{tabular}{|l|l|l|}
\hline \multicolumn{2}{|c|}{ PublisherInfo } \\
\hline \hline PublisherName & $:$ & BioMed Central \\
\hline \hline PublisherLocation & $:$ & London \\
\hline \hline PublisherImprintName & $:$ & BioMed Central \\
\hline \hline
\end{tabular}

\title{
MICER resource saves time
}

\begin{tabular}{|l|l|l||}
\hline \multicolumn{2}{|c|}{ ArticleInfo } \\
\hline \hline ArticleID & $:$ & 4976 \\
\hline \hline ArticleDOI & $:$ & $10.1186 /$ gb-spotlight-20040707-03 \\
\hline \hline ArticleCitationID & $:$ & spotlight-20040707-03 \\
\hline \hline ArticleSequenceNumber & $:$ & 39 \\
\hline \hline ArticleCategory & $:$ & Research news \\
\hline ArticleFirstPage & $:$ & 1 \\
\hline \hline ArticleLastPage & $:$ & 3 \\
\hline \hline & & RegistrationDate : 2004-7-7 \\
\hline ArticleHistory & $:$ & OnlineDate \\
\hline \hline ArticleCopyright & $:$ & BioMed Central Ltd2004-7-7 \\
\hline \hline ArticleGrants & $:$ & \\
\hline \hline ArticleContext & $:$ & 130595511 \\
\hline \hline
\end{tabular}


Cathy Holding

Email: cathyholding@aol.com

A new functional genomics resource, described in Nature Genetics this week, could save the scientific community millions of dollars in annotating the mouse genome, the paper's lead author said (Nat Genet 2004, DOI:10.1038/ng1388).

David Adams heads the Wellcome Trust's Mutagenic Insertion and Chromosome Engineering Resource (MICER) project, a publicly available supply of 93,960 ready made insertional targeting vectors in two libraries for generating knockouts and for large-scale deletions, inversions, or duplications. Instead of having to screen a library for a particular gene or region of interest and then find a bacterial artificial chromosome clone or a genomic clone, the clone can be found online at the MICER Web site, eliminating the effort that otherwise would be needed in generating those resources, Adams told us.

"The Wellcome Trust is very forward thinking, they are basically saving millions of dollars here," said Adams, a member in the team of Allan Bradley, director of the trust's Sanger Institute. "If they spent a bit of money making a resource like this, then the days, weeks, months that individual people in individual labs have to spend is reduced dramatically - so in the long term, it's a great saving."

"What we've done is make a library of targeting vectors. Instead of a genomic library, which has a physical bit of DNA for your genome of interest, we've done it for the whole genome at once," Bradley said. The vectors were indexed by sequencing both ends of the insert and mapping them back onto the mouse genomic sequence - generated by the Sanger and the Whitehead institutes and Washington University over the last few years.

With this online resource, a targeting vector can be identified in a matter of minutes and acquired within a few days, Bradley told us, "and that takes out a month or two of work in the lab."

The vectors also contain different positive selection markers for different vectors (either neo- or puromycin) and a coat color marker (either tyrosinase, which turns a white mouse black, or agouti, which turns a brown mouse yellow), Bradley said. The coat color marker tracks the mutations from one generation to the next. "It makes the downstream tracking very easy and avoids lots of procedures on animals. You don't have to take a biopsy or do a PCR reaction or a southern blot. It's all done by color," he said. This "downstream tracking" otherwise constituted about $20 \%$ of the work in his lab, he added.

Functional genomics research can now be done much more quickly, said James R. Lupski, at Baylor College of Medicine, who was not involved in the study. His interest in genomic disorders "where you have a rearrangement of a chunk of the genome - you have several haplo-insufficient genes that are involved in giving you the phenotype that you see," would also benefit from the resource, he added.

"They can target 1800 ensemble genes and 910 sentinel genes... And I guess this resource will grow," Roger Cox, at the Medical Research Council's Mammalian Genetics Unit, told us. Cox, who was not involved in the study, said that while this represented only about 7 to $11 \%$ of all the genes in the genome - low compared to the Sanger Institute Gene Trap Resource with an estimated 32\% genome coverage "they are complementary approaches that will ultimately help us to get to this aim of identifying every gene in the genome." 


\section{References}

1. Nature Genetics, [http://www.nature.com/ng/]

2. The Bradley Lab - Mutagenic Insertion and Chromosome Engineering Resource (MICER), [http://www.sanger.ac.uk/PostGenomics/mousegenomics/]

3. Allan Bradley, [http://www.sanger.ac.uk/Teams/Team82/]

4. James R. Lupski, [http://imgen.bcm.tmc.edu/molgen/lupski/lupski_james.html]

5. Roger D. Cox, [http://www.mgu.har.mrc.ac.uk/research/qtl/index.html]

6. Sanger Institute Gene Trap Resource, [http://www.sanger.ac.uk/PostGenomics/genetrap/] 